\section{Lässt sich der Progress von Lungenschäden verhindern?}

\author{
Indium ist ein Metall, das bei der Produktion moderner \\ elektronischer Geräte benötigt wird. In den letzten Jahren \\ zeigte sich, dass die Inhalation des Stoffes zu Lungenschäden \\ wie Granulomen, Fibrose und Emphysem führen kann. \\ Das japanische Forscherteam um A. Amata hat nun \\ Beobachtungsdaten von Indium-Arbeitern vorgelegt. \\ Thorax 2015; 70: 1040-1046
}

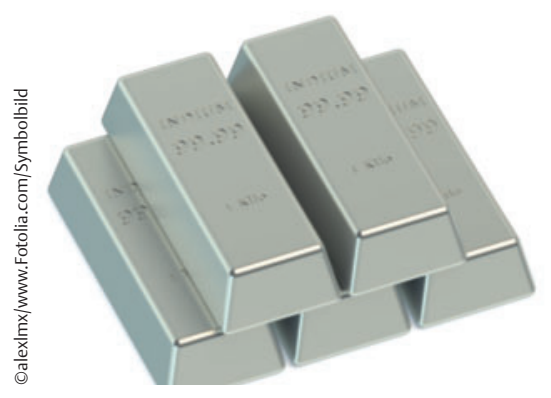

Die Autoren beobachteten hierzu 84 männliche Arbeiter über einen Zeitraum von 9 Jahren, nämlich zwischen 2002 und 2010. Während dieser Zeit dokumentierten sie die Symptome der Arbeiter, nahmen Lungenfunktionstests vor, führten Untersuchungen per Comptertomografie durch und bestimmten im Serum die Konzentrationen von Indium und verschiede-
$<3,7 \mathrm{mng} / \mathrm{ml}, 3,7-9,9 \mathrm{ng} / \mathrm{ml}, 10,0-22,4 \mathrm{ng} /$
$\mathrm{ml}$ und $>22,5 \mathrm{ng} / \mathrm{ml}$. Während des Studienzeitraums fanden kontinuierlich Ver- besserungen der Arbeitsbedingungen statt, was zu einer Veringerung der Indium-Konzentrationen in der Luft führte.

Aufgrund dieser Verbesserungen zeigten die Serumkonzentrationen von Indium bei den Arbeitern während des Studienzeitraums eine Tendenz zu niedrigeren Werten, begleitet von deutlichen Reduktionen der Konzentrationen von KL-6 und Surfactant Protein D (SP-D). In den CT-Untersuchungen waren die interstitiellen Läsionen teilweise rückläufig, während die emphysematösen Läsionen bei Arbeitern mit hohen Indium-Serumkonzentrationen progressiv zunahmen. Das Verhältnis aus $\mathrm{FEV}_{1}$ und FVC nahm über die Jahre ab, wobei die Abnahme bei Arbeitern mit hohen Indium-Serumkonzentrationen deutlich größer war. Die mediane biologische Halbwertszeit der Indium-Serumkonzentrationen wurde auf 8,09 Jahre geschätzt.

\section{Fazit}

Die Ergebnisse legen nahe, dass sich die Konzentration von Indium sowie die Spiegel von KL-6 und SP-D im Serum ebenso wie die radiologischen interstitiellen Lungenveränderungen bei IndiumArbeitern vermindern lassen, indem die Exposition gegenüber dem Metall gesenkt wird. Emphysematöse Veränderungen können dagegen bei Arbeitern mit hoher Exposition in der Vergangenheit einen Progress zeigen, so die Autoren.

\section{Dr. Johannes Weiß, Bad Kissingen}

